\title{
Plant speciation in the face of recurrent climate changes in the Alps
}

\author{
Christian Parisod ${ }^{1}[0$
}

Received: 12 February 2021 / Accepted: 26 May 2021 / Published online: 29 July 2021

(c) The Author(s) 2021

\begin{abstract}
The main, continuous mountain range of the European Alpine System (i.e., the Alps) hosts a diversified pool of species whose evolution has long been investigated. The legacy of past climate changes on the distribution of high-elevation plants as well as taxa differentially adapted to the mosaic of edaphic conditions (i.e., surmised ecotypes on calcareous, siliceous, serpentine bedrocks) and the origin of new species are here discussed based on available evidence from endemic taxa across the Alps. The integration of main spatial and ecological patterns within and among species supports speciation driven by spatial isolation in main glacial refugia where plant populations survived during cold phases and hindered by intense gene flow along main expansion pathways during warm phases. Despite patterns of genetic differentiation matching environmental heterogeneity, processes underlying the dynamics of distribution ranges likely promoted recurrent homogenization of incipient divergence and generally hindered the completion of speciation (except for cases of hybrid speciation). Even intense selective pressures on toxic bedrocks such as serpentine seemingly fail to support the completion of speciation. Accordingly, typical scenarios of ecological speciation whereby local adaptation to environmental heterogeneity initiates and supports long-term reduction of gene flow may rarely be at the origin of stable species in the Alps. Although consistent with neutral processes whereby spatial isolation driven by past climate changes promoted reproductive isolation and yielded limited diversification, mechanisms at the origin of new species across heterogeneous landscapes of the Alps remain insufficiently known. Necessary advances to reliably understand the evolution of biodiversity in the Alps and identify possible museums or cradles of variation in face of climate changes are discussed.
\end{abstract}

Keywords Adaptation $\cdot$ Endemic species $\cdot$ Phylogeography $\cdot$ Range changes

\section{Introduction}

The Alps (i.e., the main range of the European Alpine System) represents a coherent biogeographic unit, harboring a regional pool of high-elevation plant species that have evolved in situ and, chiefly, through exchanges with other mountain ranges of the Mediterranean area, Europe and Eurasia (Ozenda 2009). As compared to other ranges of the European Alpine System, it hosts noticeably few genera that have considerably diversified into strict endemic species (Kadereit 2017). This may appear counter-intuitive given that adaptive processes across environmentally heterogeneous landscapes are expected to promote ecological speciation (Badgley et al. 2017) and that genetically based

Christian Parisod

christian.parisod@ips.unibe.ch

1 Institute of Plant Sciences, University of Bern, Altenbergrain 21, 3013 Bern, Switzerland differentiation according to elevation has been regularly reported across several widespread plants (Halbritter et al. 2018). Offering an ideally continuous, yet topographically complex and, therefore, ecologically heterogeneous landscape, the Alps represent a convenient model system to address the relative impact of processes such as selection, genetic drift and gene flow in shaping speciation in space and time. In particular, such a landscape may facilitate the delineation of geographical (thereafter, spatial to emphasize the component independent of the environment) and ecological underpinnings of the origin of new species in a region where plants have undergone repeated cycles of range expansion-contraction during the Quaternary (Hewitt 1996).

Endemic taxa of the Alps represent a formidable opportunity to assess how historical climate changes have interacted with environmental heterogeneity in driving speciation and to address to what extent the corresponding reduction of gene flow was promoted by either spatial isolation (i.e., consistent with neutral accumulation of incompatibility 
alleles supporting reproductive isolation) or selection in contrasted environments (i.e., consistent with ecological speciation models whereby local adaptation initiates and supports reproductive isolation; Sobel et al. 2010). Following the synthesis of Aeschimann et al. (2011), the flora of the Alps encompasses 3983 native taxa out of which 2380 can be considered as typical orophytes occurring in contrasted habitats across elevation (i.e., subalpine, alpine, nival belts) and includes 501 endemic taxa. I here interpret the distribution of these endemic taxa (i.e., $12.6 \%$ of the native flora of the Alps) in the light of patterns left by climate-driven cycles of range shifts to discuss main processes underlying speciation across ecologically heterogeneous landscapes in the Alps. Although the age of species is poorly known, only few paleoendemics are known (e.g., Saxifraga florulenta; Patsiou et al. 2014) and the more than $25 \%$ of endemic taxa being ranked as subspecies can be regarded as likely neoendemics suggestive of active speciation in the Alps. Based on current knowledge of main refugia having supported the survival and isolation of plant populations during the last glacial maximum (LGM) as well as main post-glacial expansion pathways having promoted secondary contact and gene flow among previously isolated populations (Fig. 1), I discuss the legacy of past climate changes on the distribution of variation in high-elevation endemic plants as well as taxa differentially adapted to the mosaic of edaphic conditions (i.e., surmised ecotypes on calcareous, siliceous, serpentine bedrocks). Available insights are integrated to address the main spatial and ecological drivers of speciation in the Alps and highlight remaining gaps in knowledge.

\section{Historical constraints on the origin of high-elevation species in the Alps}

Comprehensive analyses of Smyčka et al. (2017) reported higher proportions of endemic taxa (including narrow endemics) along with increasing elevation, supporting quantitative observations that high-elevation species $(27.9 \%$ of the total flora) disproportionally contribute $57.1 \%$ of all endemic taxa in the Alps (Aeschimann et al. 2011). Over the whole Alps, the proportion of endemic taxa noticeably increases from $17.5 \%$ of the native taxa across the subalpine belt to $26.9 \%$ in alpine and $30.3 \%$ in nival belts, suggesting that speciation actively contributed to such an ecologically specialized flora. In contrast to expectation of speciation chiefly driven by ecological differentiation, endemic taxa with large as well as restricted distribution ranges appear significantly enriched in the vicinity of glacial refugia such as in the South-western, Southern and Eastern Alps, and become less frequent towards the North-western Alps and the Central Alps where suitable environments are also available (Smyčka et al. 2017). Consistent with an important contribution of spatial isolation in promoting speciation, not only the Eastern Alps (Tribsch and Schönswetter 2003) but also the South-western Alps host several narrow endemics centered at high elevation and that contribute a substantial fraction of all endemic taxa of the Alps (Fig. 1). Although to a much lower extent than extremities of the Alps, putative nunataks of the Central Alps also present some narrow endemics that may have differentiated in situ and did not considerably expand (Tribsch 2004). Much remains to be ascertained regarding the impact of Central nunataks on the persistence and evolution of species during environmental changes (Schönswetter and Schneeweiss 2019).

Following differentiation driven by spatial processes during long-lasting cold phases, a majority of incipient species (i.e., local variants) had to face gene flow from recolonizing relatives that expanded their range following the retreat of ice sheets. Accordingly, vicariant taxa lacking ecogeographical isolation have been shown to hybridize following post-glacial secondary contacts (e.g., Schneeweiss et al. 2017). It is, therefore, likely that a majority of genetically differentiated populations in several species have been early swamped and gone to extinction without notice. Supporting a considerable impact of secondary contact and gene flow following expansion across previously glaciated landscapes, the North-western Alps harbor not only major hybrid zones (Thiel-Egenter et al. 2011) but also restricted patches of ancestral genetic variants surrounded by widespread lineages in several species (Parisod and Besnard 2007; Rogivue et al. 2018). Such patterns support scenarios whereby genetic differentiation accumulates in spatial isolation during cold phases and is homogenized following expansion during warm phases and suggest that speciation has been largely hindered by recurrent range contraction-expansion that brought divergent lineages into secondary contact in the Alps.

Repeated cycles of isolation in glacial refugia and secondary contact following centripetal expansion likely promoted a transverse distribution of endemic species, whereby divergent taxa had the opportunity to accumulate at the extremities of the mountain range in refugia away from the main ice domes and main recolonization pathways; whereas, widespread expanding species underwent genetic homogenization in the Central Alps (Wallis et al. 2016). Such a scenario likely explains the origin and persistence of the $28.1 \%$ and $40.3 \%$ of the strict endemic taxa that grow in the alpine belt of the South-western and the Eastern Alps, respectively (Fig. 1). Unlike endemic species from the nival belt that appear generally widespread and may have either persisted in multiple refugia or largely expended after the LGM, cycles of isolation and gene flow seem consistent with the evolution of dissimilar cohorts of endemic taxa at both extremities of the Alps.

Noticeably, gene flow among divergent taxa does not necessarily lead to homogenization and, in cases where 


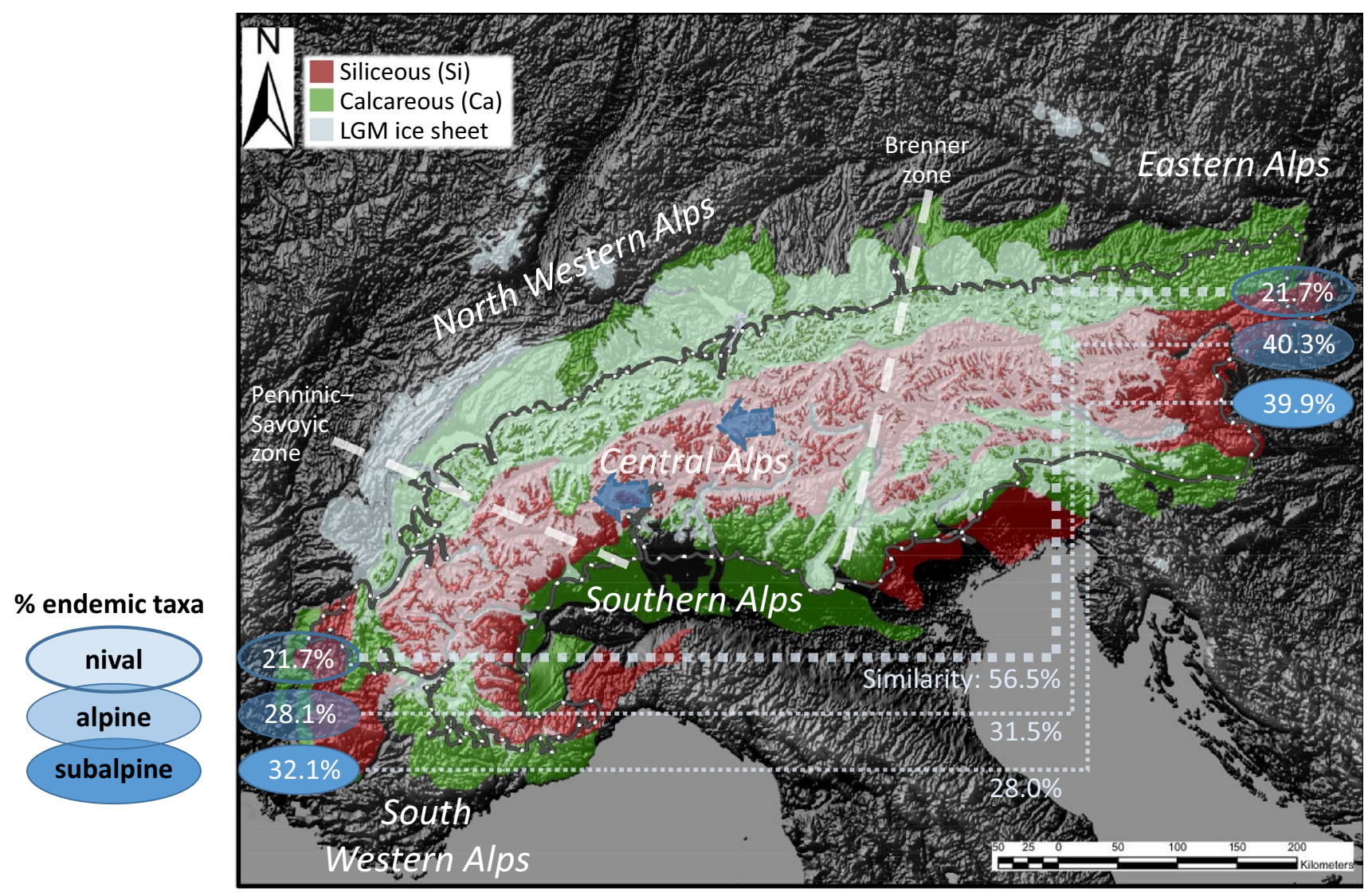

Fig. 1 Historical contraction of the distribution range of plant species in ice-free refugia during cold phases and expansion across areas left by the retreat of glaciers during warm phases in the Alps. Contraction: the survival of plant populations in climatically suitable areas (i.e., glacial refugia) not covered by ice sheets during cold phases such as the last glacial maximum (LGM) has long been studied (reviewed in Stehlik (2000); Schönswetter et al. 2005). (i) The tabula rasa hypothesis holds that all populations of the Alps went extinct in face of growing ice sheets and that species survived the LGM across low-elevation refugia around the Alps (i.e., lowland refugia). Accordingly, relatively thermophilous species likely survived in southern refugia that also sheltered competitive forest communities at low elevation (e.g., Kaltenrieder et al. 2009). Cold-adapted heliophilous taxa survived the LGM in northern lowland areas (e.g., Papaver alpinum; Pittet et al. 2020), where species from dry steppic grasslands also showed large populations (e.g., Euphorbia seguerina; Kirschner et al. 2020). (ii) The nunatak hypothesis contrastingly postulates in situ survival of plant populations across mountain tops extruding from otherwise heavily glaciated areas such as the peripheral Alps (i.e., peripheral refugia) or the Central Alps (i.e., nunatak sensu Holderegger and Thiel-Egenter 2009). In support of corresponding predictions, several high-elevation specialists were shown to have contracted into ice-free mountain tops away from the highest ice domes across the Eastern Alps (e.g., Pedicularis asplenifolia; Pan et al. 2020) and the South-western Alps (e.g., Saxifraga florulenta; Patsiou et al. 2014). Although potentially confounded with early immigration after the LGM, patterns matching survival in isolated nunataks of the Central Alps (indicated with arrows) were reported (e.g., Senecio halleri; Bettin et al. 2007). As also discussed by Schönswetter and Schneeweiss (2019), scenarios (i) and (ii) mostly rep- resent the two ends of a continuum. Expansion: recolonization of mountainous area left by the retreat of ice sheets during warm phases commonly followed centripetal expansion from lowland or peripheral refugia towards the Central Alps (Parisod 2008). Continuous areas of siliceous bedrocks in the Central Alps have expectedly favored species range shifts as compared to surrounding calcareous-rich patches of peripheral mountain ranges. Although the calcareous flora shows considerable idiosyncrasy, comparative phylogeography of widespread siliceous species from high-elevation highlighted similar break zones in the distribution of alleles and supported secondary contact in suture zones away from the location of glacial refugia. According to Thiel-Egenter et al. (2009), genetically differentiated lineages from the Southern, South-western and the North-western Alps come into sympatry along the Aosta valley, across the Penninic-Savoyic zone. Eastern, Southern and North-western lineages come into contact across the Brenner zone running from Innsbruck to Lake Garda. Despite discrepancies among studies, similar biogeographic subdivisions have been postulated based on floristic evidence across the Alps (see references in Thiel-Egenter et al. 2009). Speciation: endemic taxa in specific refugia mark the accumulation of divergent populations that likely became reproductively isolated and established new species in face of intra- and inter-specific competitors recolonizing the Alps. Accordingly, main glacial refugia in the South-western vs Eastern Alps host a large proportion of strictly endemic taxa out of all endemics of the Alps (\% endemic taxa). Similarity of endemic taxa between the South-western vs Eastern is increasing with elevation (Aeschimann et al. 2011), indicating that endemics from the nival belt are mostly shared among refugia that were colonized after speciation. A substantial fraction of the lower-elevation endemics are restricted to the vicinity of refugia and likely originated there 
unfit hybrids are formed following secondary contact, may promote either reinforcement (e.g., niche displacement) or the origin of new species through hybrid speciation (Abbott et al. 2013). As expected following the merging of cohorts of taxa with different historical backgrounds, main suture zones have been shown to harbor increased (phylo-) genetic and species diversity in the Alps (Smyčka et al. 2017). They also host several of the endemic species whose hybrid origin coincides with the LGM or post-glacial times (e.g., Kadereit 2015). Such neoendemic taxa appear to be mostly of allopolyploid origin, having recently formed close to the Penninic-Savoyic zone of secondary contact in either the North-western Alps (e.g., Arenaria bernensis, Berthouzoz et al. 2013) or the Central Alps (e.g., Draba ladina; Widmer and Baltisberger 1999). When coupled with nearly immediate postzygotic isolation through ploidy level, gene flow fostered by cycles of range expansion-contraction is indeed expected to promote the origin of new polyploid species (Stebbins 1984; Parisod et al. 2010). Accordingly, zones of secondary contact between divergent lineages, especially chromosomally divergent populations, can be predicted to foster the origin of new species. Although the global distribution of polyploids is largely associated with historical constraints at a global scale (Rice et al. 2019), the Alps still await detailed quantitative investigation.

Keeping in mind that scenarios typified as tabula rasa vs nunatak (Fig. 1) may only represent the two ends of a continuum (Schönswetter and Schneeweiss 2019), populations of orophytes likely persisted for long times around mountain tops extruding from ice sheets and therefore underwent genetic differentiation in spatial isolation (i.e., without gene flow) until they occasionally accumulated sufficient reproductive isolation to persist as stable species in the face of gene flow. As such a scenario emphasizing spatial isolation is agnostic regarding evolutionary forces at the origin of species in the Alps, neutral models should be privileged as null hypotheses before considering models whereby local adaptation to environmental heterogeneity initiates and supports speciation (Sobel et al. 2010).

\section{Edaphically specialized species in the Alps}

The distribution of species across the Alps supports specialization according to geological substrates and has often been discussed as the result of ecological speciation whereby adaptive processes driven by edaphic heterogeneity initiate genetic divergence and promote isolation in the face of gene flow. The most widespread calcareous or siliceous bedrocks are indeed known to select for different communities of calcicolous vs calcifuge plants, respectively, and such spatially stable edaphic heterogeneity could be expected as a prime factor fostering the origin of new species across the Alps. There are, however, few strict specialists of either calcareous or siliceous bedrocks (Aeschimann et al. 2012) and, despite several flagstone examples of calcicolous/calcifuge relatives, Alvarez et al. (2009) reported similar infraspecific spatial structure across multiple species showing different edaphic preferences. Accordingly, available insights indicate that climate oscillations of the Quaternary had a preponderant impact on range shifts, independent of edaphic preferences, and that calcicolous and calcifuge taxa had ample opportunities for secondary contacts during expansion. Although several species-rich genera (e.g., Campanula or Saxifraga) present multiple taxa with specialized edaphic niches, a comprehensive analysis of spatial vs ecological underpinnings of speciation is still lacking. Calcifuge species of Gentiana sect. Ciminalis were shown to have evolved independently from calcicolous ancestors (Hungerer and Kadereit 1998). Species of Sempervivum also exemplified an opposite evolution from calcifuge towards calcicolous species (Klein and Kadereit 2015). Noticeably, independent evolution of calcifuge subspecies of Adenostyles alpina occurred only in allopatry from the ancestral calcicolous stock (recognized as subsp. alpina, Dillenberger and Kadereit 2013), suggesting that spatial isolation more than adaptive processes driven by edaphic conditions was instrumental in driving the origin of ecologically specialized incipient species.

The distribution of edaphically specialized endemic taxa in the Alps offers insights on spatial and ecological processes driving speciation, despite confounding factors due to high-elevation Central Alps being mostly siliceous and surrounded by calcareous-rich peripheral mountain ranges reaching lower elevations. In particular, Smyčka et al. (2017) highlighted a considerable diversity of narrow endemics across the calcareous-rich areas surrounding the Central Alps. Following Aeschimann et al. (2012), the more than $33 \%$ calcicolous endemics contrast with the overall flora of the Alps (8\%), suggesting that calcareous-rich areas that are typically fragmented across peripheral Alps may have promoted diversification. Similarly, calcifuge endemics (24 species; $4.8 \%$ ) are slightly over-represented as compared to the overall flora $(2.1 \%)$, although calcifuge taxa are relatively widespread within the Alps and suggest that contraction-expansion across largely adjacent siliceous areas rarely promoted complete speciation (Schönswetter et al. 2005; Smyčka et al. 2017). Such a scenario whereby speciation in calcifuge species is hampered by gene flow is further supported by the relative genetic homogeneity reported within widespread calcifuge species as compared to calcicolous ones (e.g., Alvarez et al. 2009). Although genetically based preference of relatives to different bedrocks likely promoted long-term parapatry and supported the maintenance of reproductive isolation despite range shifts, the relative impact of spatial and ecological factors in initiating and driving speciation to completion remains elusive. 
Naturally toxic soils such as derived from serpentine represent a strong selective substrate that can be expected to drive ecological speciation (Harrison and Rajakaruna 2011). In the Alps, only 23 species show clear preference to such edaphic conditions (Aeschimann et al. 2012), suggesting that strong selection hardly promoted diversification across scattered areas made of serpentine. Despite several widespread species presenting specialized populations, only nine endemic species seem restricted to serpentine, mostly at low elevation. In fact, serpentine specialists such as Minuartia laricifolia subsp. ophiolitica (Moore et al. 2013) or ecotypes within Biscutella laevigata (Tremetsberger et al. 2002) seemingly have often evolved in allopatry from the main distribution range of their generalist relatives. Consistent with neutral models of speciation, several such heliophilous species may indeed have benefitted from open habitats on such stressing conditions to remain competitive in face of (the gene flow from) post-glacial recolonizers. The relative rarity of serpentine specialists among high-elevation endemic taxa of the Alps may also be partly explained by the limited availability of corresponding conditions, especially among glacial refugia. Noticeably, genetically differentiated individuals of Androsace alpina growing on serpentine around an isolated mountain top of the South-western Alps have recently been characterized as a new taxon suggestive of ecological speciation (Boucher et al. 2021). Similarly, the high-elevation endemic Phyteuma humile shows a narrow distribution range matching a Central nunatak (Zermatt area) that presents extensive serpentine and, therefore, represents a striking example suggesting that long-term persistence in spatial isolation may have promoted the origin of a specialized species (Schneeweiss et al. 2013). It should, however, be noticed that this species seemingly has divergent chromosomes as compared to relatives on calcareous and the corresponding reduction of gene flow may, thus, have been the primary driver of speciation. As is generally the case, the interplay between genetic and ecological drivers of speciation remains to be firmly assessed.

Despite evidence of differential preference to contrasted bedrocks among related plants, the Alps host relatively few strict edaphic specialists (Aeschimann et al. 2012). Further investigations of sister calcicolous vs calcifuge species, such as the cushion plants Silene acaulis vs Silene exscapa, will have to clarify the genetic architecture of adaptation and its ability to maintain species integrity in the face of gene flow. Serpentine specialists within generalist species were shown to rely on just of few divergent loci in, e.g., Silene vulgaris (Bratteler et al. 2006) or Arabidopsis arenosa (Arnold et al. 2016) and adaptation to local edaphic conditions may, therefore, support the origin of ecotypes across heterogeneous landscapes, but fail to generally yield the stable species predicted by models of ecological speciation. Although parapatry of specialized populations can be expected to support reproductive isolation, to what extent it promoted the persistence of incipient species in the face of intense gene flow imposed by climate-driven cycles of range contraction-expansion remains an open question.

\section{Museums and cradles of biodiversity across the Alps}

As reviewed here, comparative phylogeography as well as the distribution of endemic taxa across the Alps are generally supportive of similar range dynamics of plant species that oscillate between survival in similar glacial refugia during long-lasting cold phases and possible expansion towards the Central Alps where they form major suture zones mixing both the intra- and inter-specific variation during warm phases (Fig. 1). Accordingly, a large number of paleoendemic species as well as neoendemic taxa appear restricted to glacial refugia at both extremities of the Alps where they persisted in the long term in isolation from expanding relatives. Among pressing gaps in knowledge, the age of endemic species is still poorly known and future work should attempt at dating speciation events and relate them to climatic events in the Alps. Accordingly, quantitative insights shedding light on the extent to which endemic species whose distribution is currently matching glacial refugia originated in situ or persisted there following range shifts. Such knowledge can be expected to significantly advance our understanding of the impact of spatial isolation on speciation in the Alps.

Few post-glacial events of speciation were surmised in the Alps, appearing consistent with a dominant impact of gene flow possibly promoting genetic swamping and homogenization under climate oscillations. To draw firm conclusions on how cycles of isolation and gene flow shaped current patterns of biodiversity in the Alps (Taberlet et al. 2012), future work must address the spatial arrangement of glacial refugia promoting isolation and of heterogeneous environments supporting expansion for different plant species and communities. Provided that multi-species integration of ecological and demographic modeling in space and time is now achievable following, e.g., Larsson et al. (2021), further work will likely provide key quantitative insights on the impact of the different refugia, especially in the Southern Alps as well as nunataks, on the current distribution of variation within and among communities (e.g., on diverse bedrocks). If based on relatively dense sampling, it will also highlight to what extent local variants have been swamped by expanding lineages. Such refined knowledge appears crucial to understand how cycles of range contraction-expansion interacted with speciation and extinction across topographically complex landscapes such as the Alps.

Not only glacial refugia but also areas of the Alps hosting secondary contact between intraspecific lineages or species assemblages having diverged in isolation should 
be thoroughly investigated. For instance, fine-scale surveys across suture zones will likely contribute to our understanding of underpinnings of genetic swamping vs reinforcement among divergent taxa and shed further light on the impact of hybridization and polyploidy on biodiversity in the Alps. In particular, recent hybrid and polyploid species seem to represent noticeable exceptions to scenarios whereby historical gene flow hampers speciation and would deserve further study to understand the rise of new species under environmental changes (Levin 2019). Although suture zones can be expected to have promoted the origin of hybrid and polyploid species, especially following admixture between chromosomally divergent taxa, quantitative insights are lacking in the Alps. Accordingly, future work investigating the distribution of such systems will likely highlight how and to what extent cycles of range contraction-expansion can promote speciation.

Given the few study cases demonstrating continuous evolutionary diversification driven by ecological speciation along the elevation gradient or according to edaphic heterogeneity (Kadereit 2017), a neutral model whereby phases of allopatry followed by secondary contact shape the cumulative origin of new species and the overall distribution of biodiversity across the Alps can hardly be rejected. As typical scenarios of ecological speciation driven by selection in response to environmental heterogeneity may have rarely supported completion of speciation in the Alps, repeated climate-induced range shifts seemingly rather promoted the origin of new species through the differential fixation of alleles underlying reproductive isolation (i.e., mutationorder speciation; Schluter 2009). Although the complexity of evolutionary processes overlaid with the imprint of several cold and warm phases during the Pleistocene makes it challenging to infer specific drivers of speciation, future work should tentatively quantify the relative importance of historical vs ecological factors in shaping species in the Alps. As shown by the numerous incipient species (e.g., ecotypes) reported as locally adapted to contrasted habitats in the Alps, selection by ecological agents appears effective in determining locally adapted taxa, but may be insufficient to stably limit gene flow (i.e., ecogeographic isolation) and support complete speciation (Sobel et al. 2010). To what extent genetic mechanisms that intrinsically reduce gene flow such as chromosomal rearrangements or polyploidy have contributed to the origin of ecologically specialized endemic species is still poorly documented. To decipher the drivers of speciation in the Alps, future work will have to further address the genetic architecture of traits underlying adaptation to environmental heterogeneity and how adaptive loci persist in the face of gene flow to contribute building up stable species (Rieseberg and Willis 2007). An elegant approach to shed light on the accumulation of reproductive barriers during the rise of new species in the Alps would be to compare closely related taxa encompassing a gradient from incipient species (i.e., ecotype and subspecies) to fully independent species (Via 2009). The Alps host valuable model systems to be investigated in details to highlight driving processes from initial to complete speciation.

Provided that a significant fraction of species in the Alps is currently facing strong environmental challenges (Engler et al. 2011), it is time to further assess underpinnings of plant speciation and diversification to predict the fate of biodiversity. In particular, future work will have to refine our understanding of evolutionary museums contributing to the accumulation of standing variation and cradles that support evolutionary processes generating new variation, as both merit specific attention regarding the future management of biodiversity (Moritz 2002).

Acknowledgements I would like to thank Sandra Grünig, Joachim Kadereit, Sébastien Lavergne, Peter Schönswetter and anonymous reviewers for valuable comments on this manuscript as well as Theofania Patsiou for the basemap of Fig. 1.

Funding Open Access funding provided by Universität Bern. No funding was received to assist with the preparation of this manuscript.

\section{Declarations}

\section{Conflict of interest None.}

Ethical approval The author has no relevant financial or non-financial interests to disclose.

Open Access This article is licensed under a Creative Commons Attribution 4.0 International License, which permits use, sharing, adaptation, distribution and reproduction in any medium or format, as long as you give appropriate credit to the original author(s) and the source, provide a link to the Creative Commons licence, and indicate if changes were made. The images or other third party material in this article are included in the article's Creative Commons licence, unless indicated otherwise in a credit line to the material. If material is not included in the article's Creative Commons licence and your intended use is not permitted by statutory regulation or exceeds the permitted use, you will need to obtain permission directly from the copyright holder. To view a copy of this licence, visit http://creativecommons.org/licenses/by/4.0/.

\section{References}

Abbott R, Albach D, Ansell S, Arntzen JW, Baird SJE, Bierne N, Boughman J, Brelsford A, Buerkle CA, Buggs R, Butlin RK, Dieckmann U, Eroukhmanoff F, Grill A, Cahan SH, Hermansen JS, Hewitt G, Hudson AG, Jiggins C, Jones J, Keller B, Marczewski T, Mallet J, Martinez-Rodriguez P, Möst M, Mullen S, Nichols R, Nolte AW, Parisod C, Pfennig K, Rice AM, Ritchie MG, Seifert B, Smadja CM, Stelkens R, Szymura JM, Väinölä R, Wolf JBW, Zinner D (2013) Hybridization and speciation. J Evol Biol 26:229-246. https://doi.org/10.1111/j.1420-9101.2012.02599.x

Aeschimann D, Rasolofo N, Theurillat JP (2011) Analyse de la flore des Alpes. 2: biodiversité et chorologie. Candollea 66:225-253 
Aeschimann D, Rasolofo N, Theurillat JP (2012) Analyse de la flore des Alpes. 4: écologie. Candollea 67:193-219

Alvarez N, Thiel-Egenter C, Tribsch A, Holderegger R, Manel S, Schönswetter P, Taberlet P, Brodbeck S, Gaudeul M, Gielly L, Küpfer P, Mansion G, Negrini R, Paun O, Pellecchia M, Rioux D, Schüpfer F, van Loo M, Winkler M, Gugerli F (2009) History or ecology? Substrate type as a major driver of spatial genetic structure in alpine plants. Ecol Lett 12:632-640. https://doi.org/ 10.1111/j.1461-0248.2009.01312.x

Arnold BJ, Lahner B, DaCosta JM, Weisman CM, Hollister JD, Salt DE, Bomblies K, Yant L (2016) Borrowed alleles and convergence in serpentine adaptation. Proc Natl Acad Sci USA 113:8320 8325. https://doi.org/10.1073/pnas.1600405113

Badgley C, Smiley TM, Terry R, Davis EB, DeSantis LRG, Fox DL, Hopkins SSB, Jezkova T, Matocq MD, Matzke N, McGuire JL, Mulch A, Riddle BR, Roth VL, Samuels JX, Strömberg CAE, Yanites BJ (2017) Biodiversity and topographic complexity: modern and geohistorical perspectives. Trends Ecol Evol 32:211-226. https://doi.org/10.1016/j.tree.2016.12.010

Berthouzoz M, Maendly S, Bétrisey S, Mangili S, Prunier P, Lexer C, Kozlowski G (2013) Some like it cold: distribution, ecology and phylogeny of Arenaria bernensis Favarger (Caryophyllaceae) from the western Prealps in Switzerland. Alp Bot 123:65-75. https://doi.org/10.1007/s00035-013-0116-5

Bettin O, Cornejo C, Edwards PJ, Holderegger R (2007) Phylogeography of the high alpine plant Senecio halleri (Asteraceae) in the European Alps: in situ glacial survival with postglacial stepwise dispersal into peripheral areas. Mol Ecol 16:2517-2524

Boucher FC, Dentant C, Ibanez S, Capblancq T, Boleda M, Boulangeat L, Smyčka J, Roquet C, Noûs C, Lavergne S (2021) Discovery of cryptic plant diversity in one of the harshest environments: the rooftops of the Alps. bioRxiv. https://doi.org/10. 1101/2020.06.10.144105

Bratteler M, Lexer C, Widmer A (2006) Genetic architecture of traits associated with serpentine adaptation of Silene vulgaris. J Evol Biol 19:1149-1156. https://doi.org/10.1111/j.1420-9101.2006. 01090.x

Dillenberger MS, Kadereit JW (2013) The phylogeny of the European high mountain genus Adenostyles (Asteraceae-Senecioneae) reveals that edaphic shifts coincide with dispersal events. Am J Bot 100:1171-1183. https://doi.org/10.3732/ajb.1300060

Engler R, Randin CF, Thuiller W, Dullinger S, Zimmermann NE, Araújo MB, Pearman PB, Le Lay G, Piedall C, Albert CH, Choler P, Coldea G, Lamo X, Dirnböck T, Gégout J-C, GómezGarcía D, Grytnes J-A, Heegard E, Hoistad F, Nogués-Bravo D, Normand S, Puscs M, Sebastia M-T, Stanisci A, Theurillat J-P, Trivedi MR, Vittoz P, Guisan A (2011) 21st century climate change threatens mountain flora unequally across Europe. Glob Change Biol 17:2330-2341. https://doi.org/10.1111/j.13652486.2010.02393.x

Halbritter AH, Fior S, Keller I, Billeter R, Edwards PJ, Holderegger R, Karrenberg S, Pluess AR, Widmer A, Alexander JM (2018) Trait differentiation and adaptation of plants along elevation gradients. J Evol Biol 31:784-800. https://doi.org/10.1111/jeb.13262

Harrison S, Rajakaruna N (2011) Serpentine. The evolution and ecology of a model system. University of California Press, Berkley, p 464

Hewitt G (1996) Some genetic consequences of ice ages, and their role in divergence and speciation. Biol J Lin Soc 58:247-276. https:// doi.org/10.1006/bij1.1996.0035

Holderegger R, Thiel-Egenter C (2009) A discussion of different types of glacial refugia used in mountain biogeography and phylogeography. J Biogeogr 36:476-480. https://doi.org/10.1111/j.13652699.2008.02027.x

Hungerer KB, Kadereit JW (1998) The phylogeny and biogeography of Gentiana L. sect. Ciminalis (Adans.) Dumort.: a historical interpretation of distribution ranges in the European high mountains. Perspect Plant Ecol Evol Systematics 1:121-135. https:// doi.org/10.1078/1433-8319-00055

Kadereit JW (2015) The geography of hybrid speciation in plants. Taxon 64:673-687

Kadereit JW (2017) The role of in situ species diversification for the evolution of high vascular plant species diversity in the European Alps-a review and interpretation of phylogenetic studies of the endemic flora of the Alps. Persp Plant Ecol Evol Systematics 26:28-38. https://doi.org/10.1016/j.ppees.2017.03.002

Kaltenrieder P, Belis CA, Hofstetter S, Ammann B, Ravazzi C, Tinner W (2009) Environmental and climatic conditions at a potential glacial refugial site of tree species near the Southern Alpine glaciers. New insights from multiproxy sedimentary studies at Lago della Costa (Euganean hills, northeastern Italy). Quaternary Sci Rev 28:2647-2662. https://doi.org/10.1016/j.quascirev.2009.05. 025

Kirschner P, Záveská E, Gamisch A, Hilpold A, Trucchi E, Paun O, Sanmartín I, Schlick-Steiner BC, Frajman B, Arthofer W, Steiner FM, Schönswetter P (2020) Long-term isolation of European steppe outposts boosts the biome's conservation value. Nat Commun 11:1968. https://doi.org/10.1038/s41467-020-15620-2

Klein JT, Kadereit JW (2015) Phylogeny, biogeography, and evolution of edaphic association in the European oreophytes Sempervivum and Jovibarba (Crassulaceae). Int J Plant Sci 176:44-71. https:// doi.org/10.1086/677948

Larsson DJ, Pan D, Schneeweiss GM (2021) Addressing alpine plant phylogeography using integrative distributional, demographic and coalescent modeling. Alp Bot. https://doi.org/10.1007/s00035021-00263-w (in this issue)

Levin DA (2019) Plant speciation in the age of climate change. Ann Bot 124:769-775. https://doi.org/10.1093/aob/mcz108

Moore AJ, Merges D, Kadereit JW (2013) The origin of the serpentine endemic Minuartia laricifolia subsp. ophiolitica by vicariance and competitive exclusion. Mol Ecol 22:2218-2231. https://doi.org/ $10.1111 /$ mec. 12266

Moritz C (2002) Strategies to protect biological diversity and the evolutionary processes that sustain it. Syst Biol 51:238-254

Ozenda P (2009) On the genesis of the plant population in the Alps: new or critical aspects. Comptes Rendus Biol 332:1092-1103. https://doi.org/10.1016/j.crvi.2009.09.018

Pan D, Hülber K, Willner W, Schneeweiss GM (2020) An explicit test of Pleistocene survival in peripheral versus nunatak refugia in two high mountain plant species. Mol Ecol 29:172-183. https://doi. org $/ 10.1111 /$ mec. 15316

Parisod C, Besnard G (2007) Glacial in situ survival in the western Alps and polytopic autopolyploidy in Biscutella laevigata L. (Brassicaceae). Mol Ecol 16:2755-2767. https://doi.org/10.1111/j. 1365-294X.2007.03315.x

Parisod C (2008) Postglacial recolonisation of plants in the western Alps of Switzerland. Bot Helv 118:1-12

Parisod C, Holderegger R, Brochmann C (2010) Evolutionary consequences of autopolyploidy. New Phytol 186:5-17. https://doi.org/ 10.1111/j.1469-8137.2009.03142.x

Patsiou TS, Conti E, Zimmermann NE, Theodoridis S, Randin CF (2014) Topo-climatic microrefugia explain the persistence of a rare endemic plant in the Alps during the last 21 millennia. Glob Chang Biol 20:2286-2300. https://doi.org/10.1111/gcb.12515

Pittet L, Fragnière Y, Grünig S, Bétrisey D, Clément F, Gerber C, Ronikier M, Kozlowski G, Parisod C (2020) Genetic structure of the endemic Papaver occidentale indicates survival and immigration in the western Prealps. Alp Bot 130:129-140

Rice A, Šmarda P, Novosolov M, Drori M, Glick L, Sabath N, Meiri S, Belmaker J, Mayrose I (2019) The global biogeography of polyploid plants. Nat Ecol Evol 3:265-273. https://doi.org/10.1038/ s41559-018-0787-9 
Rieseberg LH, Willis JH (2007) Plant speciation. Science 317:910914. https://doi.org/10.1126/science.1137729

Rogivue A, Graf R, Parisod C, Holderegger R, Gugerli F (2018) The phylogeographic structure of Arabis alpina in the Alps shows consistent patterns across different types of molecular markers and geographic scales. Alp Bot 128:35-45. https://doi.org/10.1007/ s00035-017-0196-8

Schluter D (2009) Evidence for ecological speciation and its alternative. Science 323:737-741

Schneeweiss GM, Pachschwoll C, Tribsch A, Schonswetter P, Barfuss MH, Esfeld K, Weiss-Schneeweiss H, Thiv M (2013) Molecular phylogenetic analyses identify Alpine differentiation and dysploid chromosome number changes as major forces for the evolution of the European endemic Phyteuma (Campanulaceae). Mol Phylogenet Evol 69:634-652. https://doi.org/10.1016/j.ympev.2013. 07.015

Schneeweiss GM, Winkler M, Schönswetter P (2017) Secondary contact after divergence in allopatry explains current lack of ecogeographical isolation in two hybridizing alpine plant species. $\mathrm{J}$ Biogeor 44:2575-2584. https://doi.org/10.1111/jbi.13071

Schönswetter P, Stehlik I, Holderegger R, Tribsch A (2005) Molecular evidence for glacial refugia of mountain plants in the European Alps. Mol Ecol 14:3547-3555. https://doi.org/10.1111/j.1365294X.2005.02683.x

Schönswetter P, Schneeweiss GM (2019) Is the incidence of survival in interior Pleistocene refugia (nunataks) underestimated? Phylogeography of the high mountain plant Androsace alpina (Primulaceae) in the European Alps revisited. Ecol Evol 9:4078-4086. https://doi.org/10.1002/ece3.5037

Smyčka J, Roquet C, Renaud J, Thuiller W, Zimmermann NE, Lavergne S (2017) Disentangling drivers of plant endemism and diversification in the European Alps-a phylogenetic and spatially explicit approach. Persp Plant Ecol Evol Syst 28:19-27. https://doi.org/ 10.1016/j.ppees.2017.06.004

Sobel JM, Chen GF, Watt LR, Schemske DW (2010) The biology of speciation. Evolution 64:295-315. https://doi.org/10.1111/j.15585646.2009.00877.x

Stebbins GL (1984) Polyploidy and the distribution of arctic-alpine flora: new evidence and a new approach. Bot Helv 94:1-11

Stehlik I (2000) Nunataks and peripheral refugia for alpine plants during quaternary glaciation in the middle part of the Alps. Bot Helv 110:25-30

Taberlet P, Zimmermann NE, Englisch T, Tribsch A, Holderegger R, Alvarez N, Niklfeld H, Coldea G, Mirek Z, Moilanen A, Ahlmer W, Marsan PA, Bona E, Bovio M, Choler P, Cieslak E, Colli L,
Cristea V, Dalmas JP, Frajman B, Garraud L, Gaudeul M, Gielly L, Gutermann W, Jogan N, Kagalo AA, Korbecka G, Kupfer P, Lequette B, Letz DR, Manel S, Mansion G, Marhold K, Martini F, Negrini R, Nino F, Paun O, Pellecchia M, Perico G, PiekosMirkowa H, Prosser F, Puscas M, Ronikier M, Scheuerer M, Schneeweiss GM, Schonswetter P, Schratt-Ehrendorfer L, Schupfer F, Selvaggi A, Steinmann K, Thiel-Egenter C, van Loo M, Winkler M, Wohlgemuth T, Wraber T, Gugerli F, IntraBioDiv C, Vellend $M$ (2012) Genetic diversity in widespread species is not congruent with species richness in alpine plant communities. Ecol Lett 15:1439-1448. https://doi.org/10.1111/ele.12004

Thiel-Egenter C, Alvarez N, Holderegger R, Tribsch A, Englisch T, Wohlgemuth T, Colli L, Gaudeul M, Gielly L, Jogan N, Linder HP, Negrini R, Niklfeld H, Pellecchia M, Rioux D, Schönswetter P, Taberlet P, van Loo M, Winkler M, Gugerli F (2011) Break zones in the distributions of alleles and species in alpine plants. $\mathrm{J}$ Biogeor 38:772-782. https://doi.org/10.1111/j.1365-2699.2010. 02441.x

Tremetsberger K, König C, Samuel R, Pinsker W, Stuessy TF (2002) Infraspecific genetic variation in Biscutella laevigata (Brassicaceae): new focus on Irene Manton's hypothesis. Plant Syst Evol 233:163-181

Tribsch A, Schönswetter P (2003) Patterns of endemism and comparative phylogeography confirm palaeoenvironmental evidence for Pleistocene refugia in the eastern Alps. Taxon 52:477-497

Tribsch A (2004) Areas of endemism of vascular plants in the eastern Alps in relation to Pleistocene glaciation. J Biogeogr 31:747-760. https://doi.org/10.1111/j.1365-2699.2004.01065.x

Via S (2009) Natural selection in action during speciation. Proc Natl Acad Sci USA 106:9939-9946. https://doi.org/10.1073/pnas. 0901397106 (Suppl 1)

Wallis GP, Waters JM, Upton P, Craw D (2016) Transverse alpine speciation driven by glaciation. Trends Ecol Evol 31:916-926. https://doi.org/10.1016/j.tree.2016.08.009

Widmer A, Baltisberger M (1999) Molecular evidence for allopolyploid speciation and a single origin of the narrow endemic Draba ladina (Brassicaceae). Am J Bot 86:1282. https://doi.org/10.2307/ 2656776

Publisher's Note Springer Nature remains neutral with regard to jurisdictional claims in published maps and institutional affiliations. 